\title{
Jonathan Dorn
}

\section{Introduction}

reetings from the Before Time. It's spring 2020, and

the specter of 7 million virus-plagued Americans remains distant and incomprehensible. The West Coast isn't burning, RGB is hanging in there, and there's little worry about a peaceful transition of presidential power. The days are getting warmer, and hope is growing that a few weeks of mask wearing will bring the economy roaring back. And somewhere in Minneapolis, there's a forty-six-year-old guy shooting hoops on a cracked blacktop court, unknown to the world, and still breathing.

From our vantage point in these early days of May, we couldn't possibly predict the calamities that will make this year unlike any we've experienced. Not the Second Surge, not 50 million unemployed, not the murder of a young EMT in Louisville, not the hellfire that will permanently eliminate any reasonable doubt about global warming. And certainly not the shaky street-corner video that is going to ignite antiracism protests from coast to coast.

Or maybe, sitting here in May, we could predict it all. George Floyd. Breonna Taylor. An economy in shambles. Thousands upon thousands of lonely deaths cutting short robust lives without respect to age or station.

After all, we've had ample warning in the stories featured in this compilation of 2019's best magazine writing. No matter 
that they'll be a year old by the time this book reaches you, or that their lighter moments will seem a bit quaint (in-person interviews, how precious! mask-free socializing-was that a thing?). No matter that they lack the underlying bewilderment so pervasive in the journalism we'll read months from now. The writing in this collection is shockingly prescient for a Before Time collection.

Take Nikole Hannah-Jones's tour-de-force essay from "The 1619 Project," a special issue of the New York Times Magazine. A previous National Magazine Award winner, Hannah-Jones incisively crystallizes the modern-day relevance of a 400-year legacy of racial injustice in her introduction to this issue. Like the rest of the issue, a towering work of journalism that spurred (and advanced) national debate, she's looking back while looking forward. It's impossible to read her words and not recognize that a national reckoning on race is right around the corner.

Similarly, three stories reporting on deep inequities in America's prison system are threaded with meaningful insights about the pernicious impact of a bent judicial process on marginalized communities. Piper Kerman and Keri Blakinger in separate articles in the Washington Post Magazine and Pamela in a ProPublica / New York Times joint investigation, each in their own way call our attention to the daily effects of institutional racism on incarcerated people of color.

And don't forget Erika Fry's timely telling of another virus story in "Epidemic of Fear." This Fortune feature and National Magazine Award finalist is a disconcerting tale of vaccine blunders and misinformation that should serve as a pressing reminder of how complex your challenge will be this fall in trusting the word of pharmaceutical companies racing for a cure in a heated political environment.

Together, these powerful stories and the others in this collection remind us why magazine journalism matters so much. The medium is uniquely equipped to synthesize current events and 
historical realities into thoughtful outlooks on the road ahead. It enables writers to make the past present and to warn us, directly or indirectly, of the challenges we will face as individuals and as a nation. And magazines provide an important and nuanced counterbalance to the attention-deprived blurb economy of Twitter and Facebook.

Read these stories, relish their insights and relevance, and let's hope that next year's volume of Best American Magazine Writing is all about the After Time. 
